\title{
Tourism Information System at Doka Tawa Tana Tourism Village Maumere
}

\author{
Robinson A. Wadu ${ }^{1}$, Nicodemus M. Setiohardjo ${ }^{1}$, Imanuel Chr. Mauko ${ }^{1}$ \\ \{robinwadu@gmail.com,nicoluck81@gmail.com, imanuelmauko@yahoo.com\} \\ Jurusan Teknik Elektro, Politeknik Negeri Kupang ${ }^{1}$
}

\begin{abstract}
Doka-Tawa-Tana is a cultural and local wisdom-based tourist destination located at Maumere, NTT. Doka-Tawa-Tana creative in packages the form of dance, music, culinary and souvenirs in the form of organic weaving to become a tourist attraction that attracts tourists to visit. In addition to earning income from the sale of woven fabrics purchased by tourists as souvenirs, Doka-Tawa-Tana also gets income from tourist visits. There are no special promotional activities carried out, either through print, electronic or online media. Information about Doka-Tawa-Tana is spread through stories, testimonials, photos and videos uploaded by tourists who have visited through online media such as Facebook, WhatsApp and Youtube. Online-based information systems are needed so that the reservation process can be carried out by tourists directly from anywhere and at any time and tourists can freely and flexibly determine the time of the visit.
\end{abstract}

Keywords: Tourism Information System, E-Tourism, Reservation System, Tourism Village, Doka-Tawa-Tana.

\section{Introduction}

Doka-Tawa-Tana is a tourism destination based on culture and local wisdom, located in Bola Maumere District, NTT. Doka-Tawa-Tana is creative in packaging packages in the form of dance, music, culinary and souvenirs in the form of organic woven into a tourist attraction that attracts the tourists to come visit. Every guest who visits will be clothed in traditional woven cloth. In addition, the Reta Lo'u welcoming dance depicts the warriors returning from the war bringing victory. Furthermore, local residents demonstrated the process of making woven fabrics ranging from making yarn from cotton, the coloring process, to the weaving process, as well as serving traditional food and beverage dishes. The arrival of domestic and foreign tourists has become one of the economic driving factors of the local community, especially since 2010 when 140 tourists organized by Floresa Tour-Travel stopped at Doka-Tawa-Tana to feel the hospitality of the community and enjoy the art of music and dance and see firsthand the fabric making process weaving. Besides earning income from selling woven fabrics that tourists buy as souvenirs, Doka-Tawa-Tana also gets income from tourist visits.

There are no specific promotional activities, either through print, electronic or online media. Information about Doka-Tawa-Tana is spread through stories, testimonies, photos and videos uploaded by tourists who have visited through online media such as Facebook, WhatsApp and Youtube. The absence of media (especially online media) that prospective tourists can use to view product information and make unlimited reservations on time and 
place is a barrier to Doka-Tawa-Tana in marketing its products which are not limited to the local level but wider to the national level even global.

The reservation process for the Doka-Tawa-Tana tour package is done through the telephone communication media or WhatsApp either by the tourists themselves or using a travel agency, then the manager arranges the schedule for the reservation made. An onlinebased information system is needed so that the reservation process can be carried out by tourists directly from anywhere and at any time and tourists can determine the time of visit as freely and flexibly as the online-based hotel reservation process that already exists on the internet.

\section{Literature review}

Digitalization has become the center of all processes in the tourism industry. The tourism product itself, because it consists of experience, consists of information that is produced and consumed even before the trip itself has begun. Online platforms, such as online travel agents, can enable MSMEs to reach more potential international tourists [1].

Information Communication Technology (ICT) plays a major role in the tourism, travel and hospitality industries. The integration of ICT in the tourism industry is very important for the success of tourism companies. ICT facilitates individuals to access tourism product information from anywhere at any time. Tourism companies can also reach targeted customers around the world in one click on the button after the advent of mobile computers, web technology, etc. [2].

E-Tourism consists of three main components [3], namely 1) data collection, standardization; 2) consolidation, management and implementation; 3) marketing. Based on this, the next [4] describes three main levels in the preparation of the E-Tourism system, namely: 1) the parts of the data collection, which are the basis for standardizing and consolidating data. In this section there are elements such as hotels, recreation areas, and important events that can be accessed by consumers. Therefore, data collection and application of standardization and consolidation are the main objectives in the first stage; 2) management and follow-up in this case include the design of a system that will be prepared based on the standardization and consolidation sections at the first level; 3) the application or application of the system that occurs in the framework of marketing. The third level is basically the level of delivery and dissemination of information to tourists.

Development of information systems as a medium for tourism promotion has been carried out, as has been done by [5] developing an E-Tourism application as a supporter of tourism promotion on the island of Lombok using the method of developing the System Development Life Cycle (SDLC). The system built can assist tourists in finding information about hotels, culinary, souvenir centers, and hospitals on the island of Lombok. [6] conducted an analysis and design of a web-based tourism information system as a promotional media in Tebo Regency using the Prototype method. According to [7] the use of the prototype method has facilitated the process of building, planning and carrying out quality control early on. The depiction in the form of a mock up can provide a preliminary description to the user about the E-Tourism that will be built, so that E-Tourism can be adjusted to the user since the beginning of the work, before entering into the design and writing code.

The development of information systems as the most common reservation media is carried out on hotel reservation systems and travel agents. [8], [9], and [10] developed a hotel 
reservation system using the SDLC method, while [11], [12], and [13] developed a hotel reservation system using a prototype method. The reservation information system at a travel agent (travel agent) was developed by [14], [15] and [16] using the SDLC method.

Based on the description above shows the research on the development of a tour package information system as a media for promotions and reservations made specifically for a particular tourist destination such as a tourist village using web engineering methods has never been done before.

\section{Research method}

The method used refers to the web engineering method proposed by [17] and carried out by [18] with the following stages of system development:

\section{a. Analysis}

Stage 1 - Analysis, this first step deals with setting strategic goals for web development and analyzing how websites can achieve these strategic goals. This analysis is divided into 6 tasks, namely:

1) Technology Analysis, identify all technological components and equipment needed to build and support this site.

2) Information Analysis, identification of information needed by users, both static (web pages) or dynamic (based on requests to the database server).

3) Analysis of skills, identifying diverse skills needed to complete the project

4) User Analysis, identify all users of the site in question. This is a much more complex process than with the development of traditional information systems as user reach, and the technology used by users, can vary greatly.

5) Cost Analysis, estimated cost for developing a site is calculated, or an estimate of what can be achieved with a predetermined budget.

6) Risk Analysis, an analysis of the main risks associated with developing this site.

\section{b. Design}

After the analysis phase is completed, the system design is based on the destination documents generated from the first stage, including information design that illustrates the web structure, data structure and functions of each feature as well as graphic design which includes layout, colors, images and animations.

\section{c. Generation}

This stage includes the construction of web sites based on design documents. All resources for site development, such as hardware and software will be selected during this step. The coding step looks at the generation of all software linked to the site and installs it on the relevant Web server. Websites must be tested against as many environments and combinations of these technologies as possible in order to maximize potential audiences.

\section{d. Implementation}

At the Implementation stage, the site must be listed in the main search engine and also carried out maintenance or system maintenance. There is an ongoing process for Web developers to adopt the new technology available. 
Repeat the whole process can then be done to implement new features and add website functionality. Stage Four shows how the website development methodology must be iterative and used nonlinearly.

\section{Results and Discussion}

Based on the stages carried out in accordance with the web development method used obtained the following results:

a. Phase 1, setting strategic objectives for developing a web-based information system that is available information and promotional media that allows Doka-Tawa-Tana to introduce their activities and products and make it easier for tourists to book tour packages directly without being limited by time and place, and flexible in determining the time of visit . From the analysis conducted obtained the following results:

1) The required technology components (minimum requirements) are MariaDB, php 7 database servers, and recommended operating systems based on Linux or Unix.

2) Identification of information needed by website users, namely tour packages, products and prices, and the availability of features for prospective tourists to make travel package reservations.

3) The skills needed for system development consist of Systems Analysts who are tasked with working on the analysis and design stages, Programmers tasked with making program (coding) following web server installation, and Operators who then operate the system on an ongoing basis.

4) System users are divided into customers, administrators and general visitors.

5) Of the four stages in web development, the biggest cost is needed at the Generation or system development stage, therefore an open source based system is chosen to minimize the costs needed to make the system.

6) The main risk associated with developing the system lies in the availability of human resources at Doka-Tawa-Tana who will manage the system in a sustainable manner.

b. Phase 2, at the Design stage, system design is carried out which includes the creation of a site map and Use Case Diagrams.

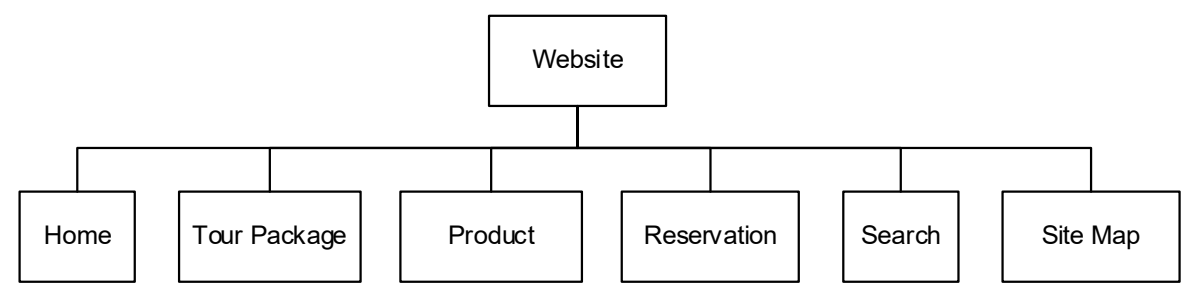

Fig. 1. Site Map.

Site Map as shown in Figure 1 shows that on the website there is a main menu consisting of Home, Daily Life, Product, Reservation, Search and Site Map.

Use Case Diagrams as shown in Figure 2 shows actors system is divided into three, namely customers, administrators and visitors. customers are given access to view news, information 
and make reservations. Administrators have the right to manage (input and delete) daily life, product and reservation data, while visitors can only view data.

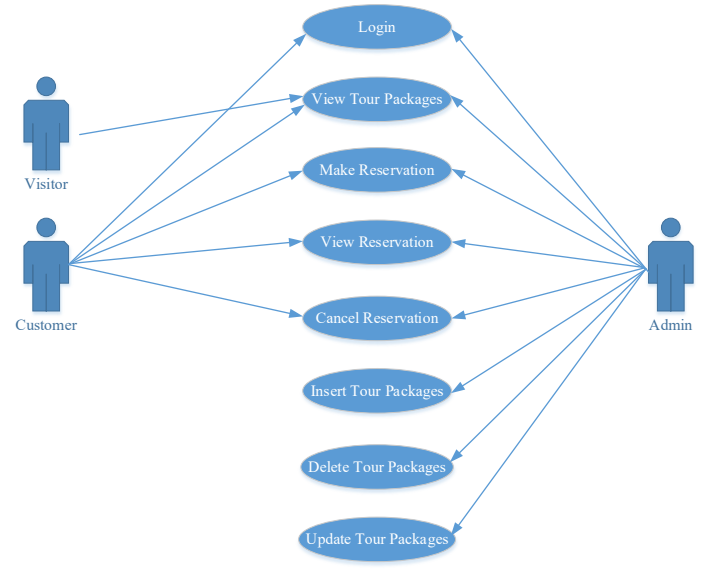

Fig. 2. Use Case Diagram.

c. Phase 3, this stage includes the construction of a web site based on the results of system design by writing source code for the program to build the system using HTML and CSS as interface design and PHP as the programming language that forms the logic of system processing and Maria DB as a database systems.

After creating a database that will be used by the system, the next step is a making an interface to the systems that been made using some tools such as HTML, CSS which are packaged in a Bootstrap's Framework. The Model of Interface structure that has been built, based on the CodeIgniter Framework which arranged in the form of MVC (Model, View and Controller). All the system interface that being shown, are arranged in 2 control files namely home.php and menu.php. The Model section in the MVC concept describes the control of database processing. This model also represents the data structure of the application which can be a database or other data. This model contains functions and classes to retrieve data, update data and delete data on the website. This model also deals with SQL query commands. The implementation of this model in the proposed web system is in the form of a PHP class function in mpaket.php that has been modified by the script according to the proposed system requirements. Below are a few lines of script from the registration and tour packages ordering system

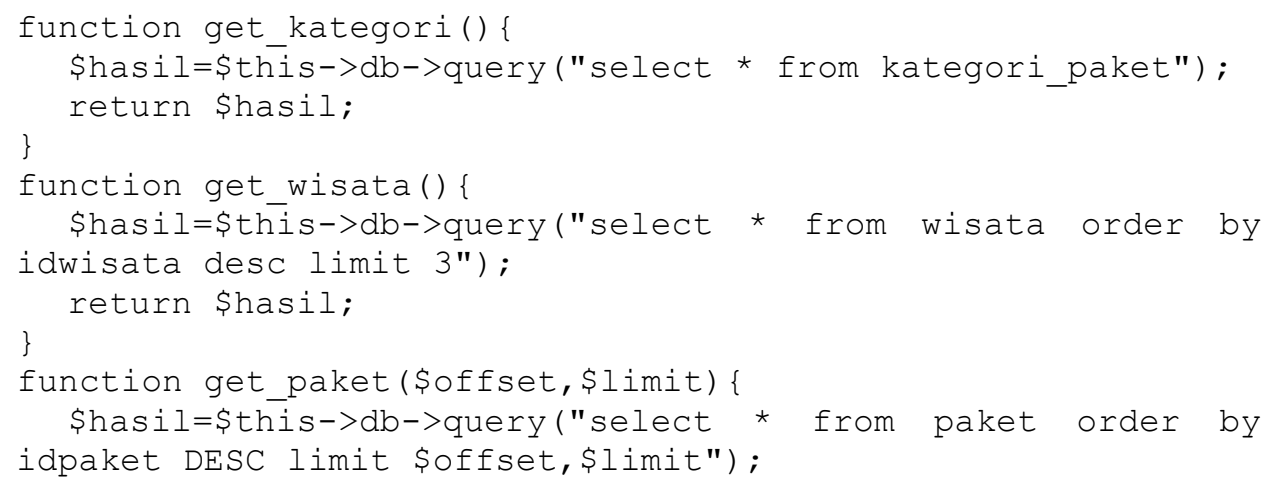




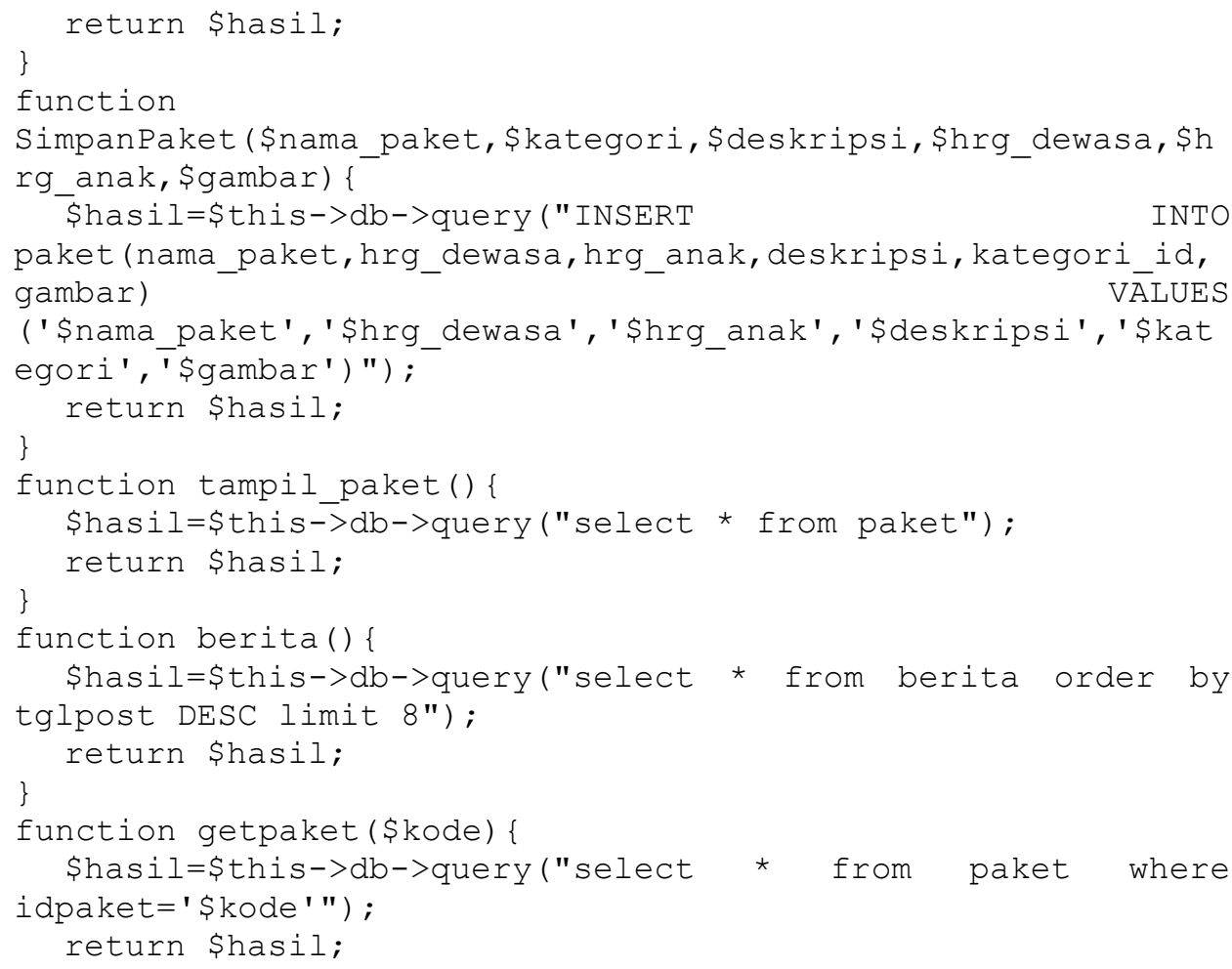

The Controller section in the MVC concept functions to control between the Model and View sections. Below are a few lines of script to control from the registration and tour packages ordering system

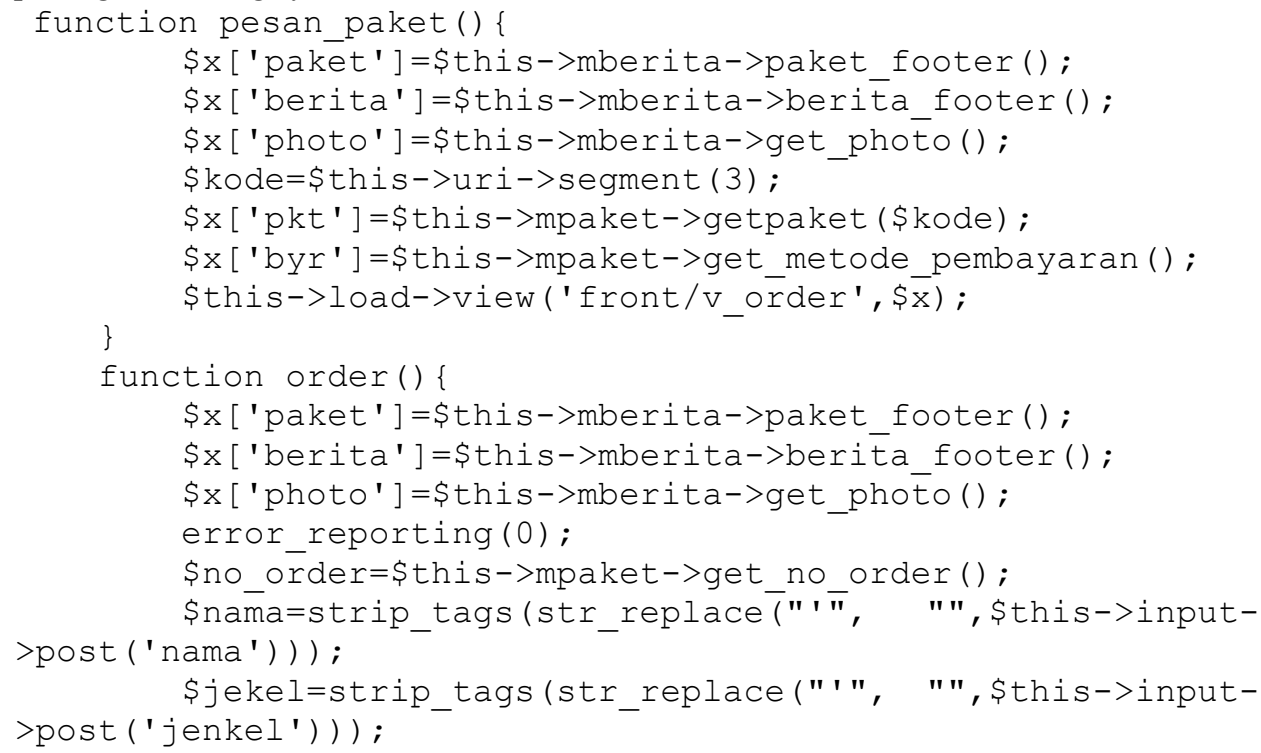




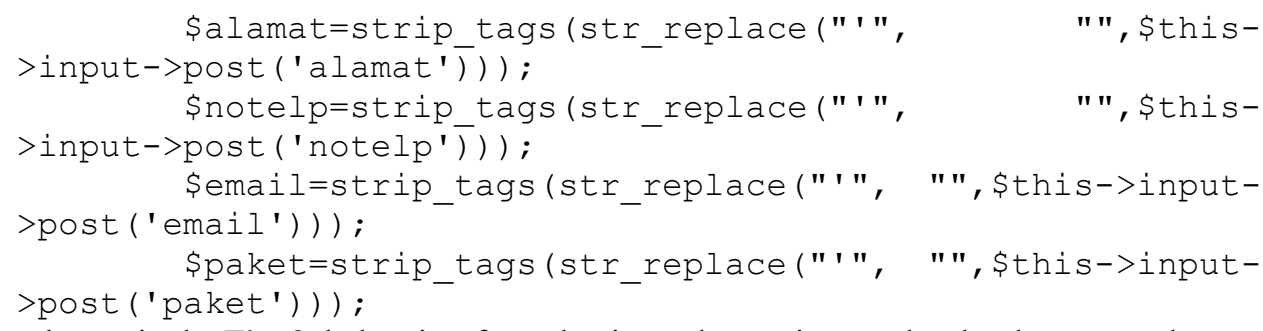

The webpage in the Fig. 3. below is a form that is used to register and order the tour package in website of Doka Tawa Tana.

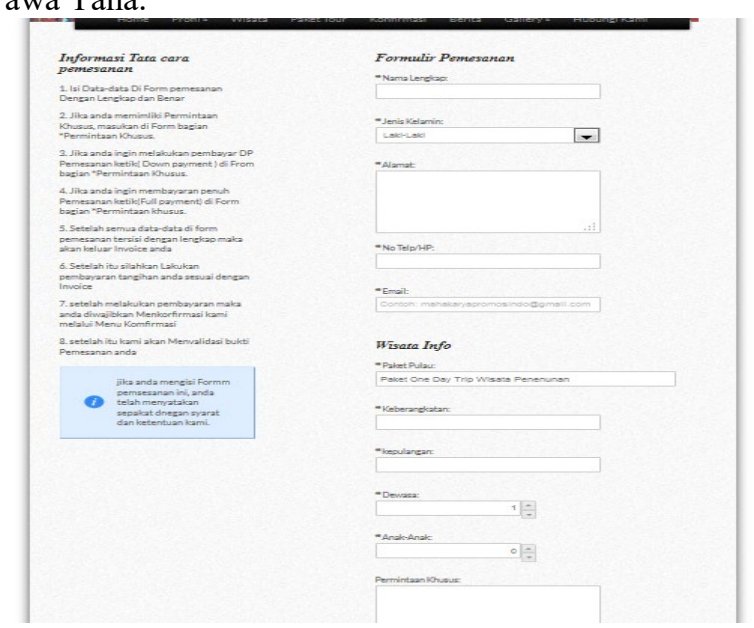

Fig. 3. Form registration and tour package ordering system

In Phase 3, testing is also carried out, both testing the system while still offline and already online. From the testing conducted based on the use case diagram, the results are obtained that each system user can access system features in accordance with the specified access rights restrictions.

Testing of the implementation of the system web based, showed that in the Fig. 4. below

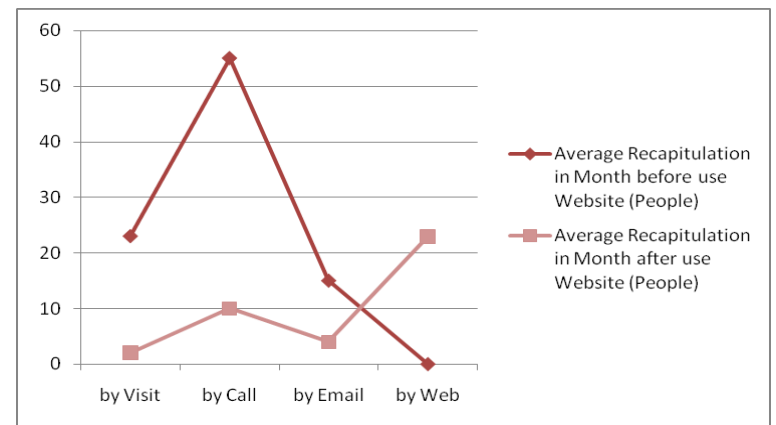

Fig. 4. Estimation Time of Recapitulation Process on access the website

That, the number of people who is coming directly to Doka-Tawa-Tana that occurred in a month, which was around $91.4 \%$, while the number of callers who asked for information and 
reservation about Doka Tana also decreased $75 \%$, then those who communicated and sent files via Social Media also decreased by $54 \%$.

d. Stage 4, due to device limitations and management resources, the implementation of the system uses server hosting. In Phase 4, a maintenance process is also carried out which is an ongoing process for web development that adopts new technology that is available and adapted to the addition of user requirements for system facilities.

\section{Conclusion}

There are similarities between the web development methods used with traditional information systems development methods, namely there are stages of goal setting, defining needs, analysis, design, system development (coding) and implementation.

With a web-based information system can help Doka-Tawa-Tana in promoting its activities and products that are not limited to the local level, but wider to the national and even global level, as well as making it easier for tourists to book travel packages directly without being limited by time and place, and flexible in determining the time of visit.

The System Information was improving the demand from the tourism to know more about Doka-Tawa-Tana and also to do a reservation on tour package in there. The increase in the overall service process with an average increase of $80 \%$, it is hoped that the promotion in Doka-Tawa-Tana will be better and faster.

\section{References}

[1] United Nations Conference on Trade Development, 2017, Information Economy Report 2017: Digitalization, Trade and Development, UNCTAD - United Nation

[2] Bethapudi Anand, 2013, The Role of ICT In Tourism Industry, Journal of Applied Economics and Business, Vol. 1, Issue 4 - December, 2013, pp. 67-79

[3] United Nations Conference on Trade Development, 2004, UNCTAD's E-Tourism Initiative, UNCTAD - United Nation

[4] Manuputty A.D. \& Tanaamah A.R., 2006, Kepariwisataan Berbasiskan E-Tourism di Indonesia, Jurnal Teknologi Informasi-Aiti, Vol. 3, No. 1, February 2006, pp. 52-65.

[5] Apriani \& Irfan Pahrul, 2017, Aplikasi E-Tourism sebagai Pendukung Promosi Pariwisata di Pulau Lombok, Konferensi Nasional Sistem \& Informatika 2017 STMIK STIKKOM Bali, August 10 2017.

[6] Ardhiyani R.P. \& Mulyono H., 2018, Analisis dan Perancangan Sistem Informasi Pariwisata Berbasis Web Sebagai Media Promosi Pada Kabupaten Tebo, Jurnal Manajemen Sistem Informasi, Vol. 3 No. 1., Maret 2018, pp. 952-972.

[7] Retnani W.E.Y. \& Kristianto W., 2016, Implementasi Prototye Dalam e-Tourism Desa Wisata Organik Lombok Kulon, Seminar Nasional APTIKOM (SEMNASTIKOM), Hotel Lombok Raya Mataram, October 28-29, 2016.

[8] Ismail P.S., 2011, Sistem Informasi Reservasi Sewa Kamar Hotel Berbasis Web (Studi Kasus Hotel Karlita Tegal), Fakultas MIPA Universitas Diponegoro, Semarang.

[9] Menezes M. \& Shinta Q., 2017, Rancang Bangun Sistem Informasi dan Reservasi Hotel Berbasis Web (Studi Kasus : Hotel Mahkota Timor Leste), Jurnal Teknologi Informasi dan Komunikasi, ISSN: 2087-0868, Vol. 8 No. 1., March 2017.

[10] Lathyf A. \& Safii M., 2012, Sistem Informasi Reservation Kamar Hotel Berbasis Web Pada Mesra Business \& Resort Hotel, Seminar Nasional Teknologi Informasi dan Komunikasi Terapan Semantik 2012, Semarang, June 23, 2012. 
[11] Finisiawati F., 2009, Rancang Bangun Website Untuk Hotel Kencana Brebes, Universitas Muhadi Setiabudi, Brebes.

[12] Wahyuningsih S., 2009, Sistem Informasi Reservasi Online Berbasis Web Pada Hotel Rumah Palagan Yogyakarta, Universitas Gajah Mada, Yogyakarta.

[13] Wibowo B., 2014, Rancang Bangun Sistem Informasi Reservasi Sewa Kamar Hotel Berbasis Web (Studi Kasus Hotel Green Mandarin Pekalongan), Fakultas Teknologi Informasi Universitas Stikubank (UNISBANK), Semarang.

[14] Yuniarto S.R., Desain Sistem Informasi Reservasi Paket Wisata Pada UKM Sektor Jasa Travel, Jurnal Akuntansi, Manajemen Bisnis dan Sektor Publik (JAMBSP), Vol. 7, No. 2., February 2011.

[15] Wibisono A., 2014, Perancangan Sistem Reservasi Online Travel Agent Berbasis Web, Fakultas Komunikasi dan Informatika, Universitas Muhammadiyah Surakarta, Surakarta.

[16] Alfiyatullathifah I., 2016, Sistem Informasi Paket Wisata Sebagai Media Promosi dan Reservasi Studi Kasus Pada Reyhan Tour, Fakultas Komunikasi dan Informatika, Universitas Muhammadiyah Surakarta, Surakarta.

[17] Howcroft, Debra. \& Carrol, John, 2000, A Proposed Methodology for Web Development, European Conference on Information Systems ECIS 2000 Proceedings 73.

[18] Mauko I.C., Setiohardjo N.M., \& Noach F.P., 2017, Pengembangan Website Unit Penelitian dan Pengabdian Kepada Masyarakat dan Penerapan Jurnal Elektronik Berbasis Open Source di Politeknik Negeri Kupang, Jurnal Ilmiah FLASH, Vol. 3, No. 2, December 2017. 